\title{
Clinical responses to acute blood loss in goats
}

\section{Respostas clínicas à perda sanguínea aguda em caprinos}

\author{
Erick Paiva Argolo ${ }^{1}$; Paulo Ricardo Firmino ${ }^{1}$; Jaqueline Oliveira Soares ${ }^{1}$; \\ Talyta Lins Nunes ${ }^{2}$; Maria Rociene Abrantes ${ }^{1}$; Rejane Santos Sousa ${ }^{3}$; \\ Francisco Leonardo Costa Oliveira ${ }^{3}$; Valeria Veras Paula ${ }^{4}$; Enrico Lippi Ortolani ${ }^{5}$; \\ Antonio Humberto Hamad Minervino ${ }^{6}$; Raimundo Alves Barrêto-Júnior ${ }^{4 *}$
}

\begin{abstract}
The response to blood loss is directly related to the degree of hemorrhage, but for the caprine species some aspects still need to be investigated. Therefore, the present study aimed to assess the clinical and hemodynamic effects of acute blood loss in goats. Eight healthy, adult male crossbred goats were subjected to external jugular puncture to remove $30 \%$ of the total blood volume. A physical examination and blood gas, biochemical, and hematologic analyses were performed at baseline, before blood loss (T0), and after one (T1h), six (T6h), 12 (T12h), 24 (T24h) and 72 (T72h) hours, and eight (T8d), 16 (T16d), 24 (T24d) and 32 (T32d) days after the acute blood loss event. The goats presented with tachycardia, tachypnea, and hyperthermia one hour after blood loss with a return to normal physiological values at T6h. Packed cell volume was decreased at T1h and red cell counts at T12h, both returning to baseline at T24d. There was a reduction in total protein and albumin levels at $\mathrm{T} 1 \mathrm{~h}$, both remained below baseline levels until T16d and T8d, respectively. The serum calcium concentration decreased over the period $\mathrm{T} 1 \mathrm{~h}$ to $\mathrm{T} 24 \mathrm{~h}$ and glucose increased over the period $\mathrm{T} 1 \mathrm{~h}$ to $\mathrm{T} 6 \mathrm{~h}$. The values of $\mathrm{pH}, \mathrm{TCO}_{2}$, bicarbonate, and base excess were lower at $\mathrm{T} 1 \mathrm{~h}$, while lactate increased markedly at this time. The $\mathrm{pCO}_{2}$ value only was reduced at T24h. Systolic (PS), diastolic (PD), and mean (PM) pressures were decreased at T1h. Acute loss of $30 \%$ of blood volume in goats caused changes in clinical, blood gas, and biochemical parameters, which were restored over a six-hour period, while hematologic changes were more persistent, with baseline values restored only after 24 days.
\end{abstract}

Key words: Shock. Blood gas. Hypovolemia. Blood.

\section{Resumo}

A resposta clínica à perda de sangue está diretamente relacionada ao grau de hemorragia, mas para a espécie caprinas alguns aspectos ainda precisam ser investigados. Deste modo o presente estudo teve como objetivo avaliar os efeitos clínicos e hemodinâmicos da perda aguda de sangue em caprinos. Oito caprinos adultos, mestiços, hígidos, foram submetidas a punção jugular externa para remoção de $30 \%$

\footnotetext{
${ }^{1}$ Médicos Veterinários, Discentes, Programa de Pós-Graduação em Ciência Animal, Universidade Federal Rural do Semiárido, UFERSA, Mossoró, RN, Brasil. E-mail: epargolo@hotmail.com; pauloricardo83@hotmail.com; negajaquesoares@hotmail. com; rocienevet3@hotmail.com

2 Medica Veterinária, Prof ${ }^{a}$ Dra $^{\mathrm{a}}$, Universidade Federal da Bahia, UFBA, Salvador, BA, Brasil. E-mail: talyta_lins@hotmail.com

${ }^{3}$ Médicos Veterinários, Discentes de Doutorado, Faculdade de Medicina Veterinária e Zootecnia da Universidade de São Paulo, FMVZ/USP, São Paulo, SP, Brasil. E-mail: rejanesantossousa@gmail.com; oliveiraflc@usp.br

${ }^{4}$ Médicos Veterinários, Profs., Drs., Departamento de Ciência Animal, UFERSA, Mossoró, RN, Brasil. E-mail: valeria@ufersa. edu.br; barreto@ufersa.edu.br

${ }_{5}$ Médico Veterinário, Prof. Titular, FMVZ/USP, São Paulo, SP, Brasil. E-mail: ortolani@usp.br

6 Médico Veterinário, Prof. Dr., Laboratório de Sanidade Animal, Universidade Federal do Oestes do Pará, LARSANA/UFOPA, Santarém, PA, Brasil. E-mail: ah.minervino@gmail.com

* Author for correspondence.
} 
do volume total de sangue. Foi realizado exame clínico e análises hematológicas, hemogasométricas e bioquímicas no momento basal, antes da perda de sangue (T0), e uma (T1h), seis (T6h), 12 (T12h), 24 (T24h) e 72 (T72h) horas e oito (T8d), 16 (T16d), 24 (T24d) e 32 (T32d) dias após. As cabras apresentaram taquicardia, taquipneia e hipertermia uma hora após a perda de sangue com retorno aos valores fisiológicos em T6h. O volume globular diminuiu em T1h e a contagem de células vermelhas em T12h, ambos retornando valores basais em T24d. Houve uma redução nos níveis de proteína totais e albumina em T1h, e ambos permaneceram abaixo dos níveis basais até T16d e T8d, respectivamente. A concentração sérica de cálcio diminuiu durante o período T1h para T24h e a glicose aumentou no período T1h a T6h. Os valores de $\mathrm{pH}, \mathrm{TCO}$, bicarbonato e excesso de base foram menores em T1h, enquanto o lactato aumentou acentuadamente neste momento. $\mathrm{O}$ pCO2 foi reduzida somente em T24h. As pressões sistólica (PS), diastólica (PD) e média (PM) diminuíram em T1h. A perda aguda de $30 \%$ do volume sangüíneo em cabras causou alterações nos parâmetros clínicos, hemogasométricos e bioquímicos, que foram restaurados ao longo de um período de seis horas, enquanto que as alterações hematológicas foram mais persistentes, com valores basais restaurados somente após 24 dias.

Palavras-chave: Choque. Hemogasometria. Hipovolemia. Sangue.

\section{Introduction}

Considerable blood loss may occur due to trauma, surgery, and obstetric intervention, as well as parasitic diseases. These conditions are more common during gestation and lactation, causing more cases of anemia and decreasing productivity of the animals (ABDALLA; ABDELATIF, 2008, 2010). A severe hemorrhage can occur within a few minutes or over several hours, and can threaten homeostasis by decreasing total blood volume, which can lead to hypovolemia, cardiovascular collapse, shock, and death (HAUPTMAN, CHAUDRY, 1998).

Sudden blood losses are initiated by a traumatic event and are followed by endocrine-metabolic responses and failure to maintain homeostatic mechanisms, causing decreased tissue perfusion (MANTOVANI et al., 2002). In these cases, clinical signs such as mucosal pallor, tachycardia, and weak pulse pressure are observed due to the decrease in circulating blood volume (DUTTON, 2003). The reduced tissue perfusion stimulates a series of complex events that trigger changes to cellular metabolism, which can lead to organ failure (CUNNINGHAM, 2004).

An animal's response to blood loss is directly related to the degree of bleeding. Reduction in the order of 10 to $15 \%$ of total blood volume is associated with minimal signs of shock, whereas a decrease of $20 \%$ to $35 \%$ is associated with the clinical syndrome of hypovolemic shock. Losses above $40 \%$ can be fatal (HAUPTMAN, CHAUDRY, 1998). However, regardless of the blood volume lost, compensatory mechanisms are activated in an attempt to maintain blood pressure and tissue perfusion (ABDALLA; ABDELATIF, 2008; DORR et al., 1986; SAEEDI et al., 2013; STARR et al., 2002; WIJFFELS et al., 2007).

Abdalla and Abdelatif (2008) evaluated the loss of 15 and $30 \%$ of blood volume in goats and observed a decrease in packed cell volume and hemoglobin concentration and an increase in rectal temperature. However, it is still necessary to investigate other parameters such as blood pressure, acid-base balance, as well as the efficiency of the hematopoietic and compensatory mechanisms involved in the restoration of homeostasis, following blood loss in goats. Furthermore, there are no studies of acute blood loss in mixed breed goats raised in the northeast region of Brazil, that present a high rusticity (COSTA et al., 2010). The objective of this study was to evaluate the clinical outcomes in goats subjected to acute blood loss with a $30 \%$ reduction in total blood volume.

\section{Material and Methods}

The experiment was approved by the Committee on Ethics in the Use of Animals of the Federal Rural 
Semiarid University (Protocol no 23091.000419 / 2013-18).

Eight healthy, castrated male goats weighing $34.75 \pm 4.3 \mathrm{~kg}$, were included in the study. The animals were allocated to two collecting pens of $20 \mathrm{~m}^{2}$ each, where they remained for an adaptation period of 30 days. At the beginning of the adaptation period the animals were dewormed (Cydentin, Zoetis, Campinas, SP) and treated with a coccidiostatic drug (Coccifin, Ouro fino, Cravinhos, SP). Each week during the adaptation period and throughout the experiment, fecal egg counts per gram (ECG) were calculated. Results were negative at all evaluation times. Animals were fed a diet of $70 \%$ Tifton hay and 30\% commercial concentrate (Max Caprinos, DuRancho, Pesqueira, PE), offered twice a day and calculated as $2.7 \%$ of body weight on a dry matter basis. The goats also received mineral mixture (Caprinofós, Tortuga, SP) and water ad libitum.

After the adaptation period, the animals were subjected to acute blood loss by external jugular puncture, and $30 \%$ of total blood volume (calculated as $8 \%$ of body weight) was removed. For blood collection, the animals were manually restrained in the right lateral decubitus position and subjected to cervical antisepsis followed by jugular vein puncture, using a $14 \mathrm{G}$ catheter attached to a blood bag. Blood was withdrawn using gravity and the volume removed per animal was monitored using an analytical balance (model AS-2000C) with a sensitivity of $0.01 \mathrm{~g}$, using a ratio of $1 \mathrm{~mL}$ of blood equals $1 \mathrm{~g}$ (SILVERTHORN, 2010). Blood withdrawal was performed early in the morning from the animals, which were kept in individual pens where the ambient temperature did not exceed $28^{\circ} \mathrm{C}$ during the trial period. Removal of blood took $10 \pm 2$ minutes and $834 \pm 11 \mathrm{~g}$ of blood per animal was withdrawn.

Clinical signs and the blood gas, hematological, and biochemical parameters were evaluated at predetermined times $(\mathrm{T})$ : $\mathrm{T} 0$ (immediately before blood loss), one (T1h), six (T6h), 12 (T12h), 24 (T24h), 72 (T72h) hours, and eight (T8d), 16 (T16d), 24 (T24d), and 32 (T32d) days after blood withdrawal. However, systolic, diastolic, and mean pressures were assessed only at times T0 (immediately before blood loss), T1 (immediately after blood loss), and one (T1h), six (T6h), and twelve (T12h) hours after the blood loss, due to the invasiveness of this procedure.

In the clinical evaluation, the heart rate, respiratory rate, temperature, and the capillary refill time (CRT) were measured according to Pugh (2005). For blood gas evaluation, venous blood samples collected using heparinized syringes were analyzed immediately in a portable hemogasometer (i-STAT, Abbott, Illinois, USA), using commercial $\mathrm{CG} 4+$ cartridges. This analyzed $\mathrm{pH}$, oxygen pressure (pO2), carbon dioxide pressure ( $\mathrm{pCO} 2)$, oxygen saturation ( $\mathrm{SO} 2)$, bicarbonate ( $\mathrm{HCO}-3)$, base excess (BE), and total carbon dioxide (TCO2). We did not include data on $\mathrm{pO} 2$ and oxygen saturation (SO2) since the blood collected was venous.

For the biochemical evaluation, blood samples were collected in vacuum tubes without anticoagulants, and serum was obtained by centrifugation to determine the activity of aspartate aminotransferase (AST): oxaloacetate hydrazone (REITMAN; FRANKEL, 1957), gamma-glutamyl transferase (GGT): p-nitroanilide (SZASZ, 1969), and concentrations of urea: urease (TOMAS, 1998) creatinine: picric acid (BARTELS; BOHMER, 1972), total protein: biuret (TOMAS, 1998), albumin: bromocresol green (JOHNSON et al., 1999), non-ionizable calcium: arsenate (BAGINSKI et al., 1973), glucose: glucose oxidase (BARHAM; TRINDER, 1972), and lactate: L-lactate dehydrogenase (SHIMOJO et al., 1989). Biochemical measurements were performed using an automatic biochemical analyzer (Rx Daytona, Randox $^{\circledR}$, Antrim, UK), with commercial kits from the same brand. 
Blood samples were collected in vacuum tubes with ethylenediaminetetraacetic acid (EDTA) for the determination of packed cell volume, number of red blood cells, number of leukocytes, and hemoglobin concentration. The counts of red blood cells and leukocytes were performed manually in a Neubauer chamber by macrodilution, using a physiological solution for counting red cells with a 1:40 dilution and Turk's reagent for leukocyte count at a 1:21 dilution (JAIN, 1993). Measurement of packed cell volume was obtained by centrifugation of a microhematocrit tube, where the samples were centrifuged at $12,500 \mathrm{~g}$ for 15 minutes and then read on a microhematocrit table (JAIN, 1993). The total hemoglobin concentration was determined by the cyanmethemoglobin method, and a subsequent spectrophotometer reading was performed at 540 nm (HENDRIX, 2005).

The systolic, diastolic, and mean arterial pressures were measured by the invasive method, through cannulation of the auricular artery with a $22 \mathrm{G}$ catheter, with the pressure transducer positioned at heart level as a "zero" reference and coupled with a portable monitor (model DX 2020, Dixtal Collaborative Evolution, Manaus, AM).

Data were analyzed for normal distribution by the Shapiro-Wilk test. The variables that showed normal distribution were subjected to an analysis of variance using the procedure PROC MIXED for repeated measures in time. Where there were significant differences $(p<0.05)$ between the times, comparisons were made between those with the mixed-mean test. The Wilcoxon test was used to evaluate the CRT data, which had a non-normal distribution. Statistical analysis was performed using the statistical program SAS (version 9.3., SAS Institute Inc., Cary, NY, USA).

\section{Results and Discussion}

The removal of $30 \%$ of the total blood volume by jugular venipuncture was an efficient method for causing acute anemia in goats, with total hemoglobin reduced below reference values (8-12 $\mathrm{g} / \mathrm{dL}$ ) in as little as 1 hour, and a decrease in packed cell volume below reference values (22-38\%) from six hours after blood loss (JAIN, 1993).

Tachycardia and tachypnea were observed one hour after blood withdrawal (Table 1), caused by a physiological response to reduced blood volume as the animals attempted to maintain cardiac output and tissue perfusion. In a previous study, goats subjected to a loss of 15 and $30 \%$ of blood volume had increased heart and respiratory rates, with the intensity of the increase dependent on the degree of blood loss (ABDALLA; ABDELATIF, 2008). In this study, respiratory rate was five times higher than baseline one hour after blood loss, while Abdalla and Abdelatif (2008) observed an increase four times higher than baseline. Similar to this study, they reported a decrease in respiratory rate six hours after acute blood loss (ABDALLA; ABDELATIF, 2008). Heart rate, despite showing a less accentuated increase, was more affected by the loss of blood volume, returning to baseline values at least 12 hours after acute loss.

Hyperventilation is one of the main responses to acute blood loss because the respiratory system is highly sensitive to the concentration of hydrogen ions produced when there is a reduction in oxygen transport. This was evident by the significant reduction in blood $\mathrm{pH}$ at $\mathrm{T} 1 \mathrm{~h}(\mathrm{P}<0.05)$, as well as its return to baseline values at $\mathrm{T} 6 \mathrm{~h}$. Heart rate regulation, however, is affected not just by a reduction in oxygenation but is also dependent on humoral mechanisms, based on the action of vasopressin and renin-angiotensin (ABDALLA; ABDELATIF, 2008; LIPINSKA et al., 2004). But in our study, it was not possible to determine exactly when the respiratory and cardiac rates returned to baseline, since the evaluations were performed at intervals of six hours. 
Table 1. Mean and standard deviation of heart rate (HR), respiratory rate (RR), rectal temperature (RT) capillary refill time (CRT), packed cell volume (PCV), red blood cell count (RBC), total hemoglobin concentration (Hb), and number of leucocytes in goats subjected to phlebotomy ( $30 \%$ blood volume loss) at times T0 (immediately before blood loss), one (T1h), six (T6h), 12 (T12h), 24 (T24h), 72 hours (T72h), and eight (T8d), 16 (T16d), 24 (T24d), and 32 (T32d) days after blood withdrawal.

\begin{tabular}{|c|c|c|c|c|c|c|c|c|}
\hline \multirow[b]{2}{*}{ Time } & \multicolumn{8}{|c|}{ Parameters } \\
\hline & $\begin{array}{c}\mathrm{HR} \\
\text { (beat } / \mathrm{min} \text { ) }\end{array}$ & $\begin{array}{c}\mathrm{RR} \\
(\mathrm{mov} / \mathrm{min})\end{array}$ & $\begin{array}{l}\text { RT } \\
\left({ }^{\circ} \mathrm{C}\right)\end{array}$ & $\begin{array}{l}\text { CRT } \\
(\mathrm{sec})\end{array}$ & $\begin{array}{l}\text { PCV } \\
(\%)\end{array}$ & $\begin{array}{c}\mathrm{Hb} \\
(\mathrm{g} / \mathrm{dL})\end{array}$ & $\begin{array}{c}\mathrm{RBC} \\
\left(\mathrm{x} 10^{6} / \mu \mathrm{L}\right)\end{array}$ & $\begin{array}{l}\text { Leucocytes } \\
\left(\mathrm{x} 10^{3} / \mu \mathrm{L}\right)\end{array}$ \\
\hline T0 & $80^{\text {def }_{ \pm}} \pm 18.0$ & $18.0^{\mathrm{d}} \pm 3.0$ & $38.5^{\mathrm{d}} \pm 0.4$ & $1.9^{\mathrm{c} b} \pm 0.1$ & $27^{\mathrm{a}} \pm 2.9$ & $8.7^{\mathrm{a}} \pm 0.9$ & $14.7^{\mathrm{a}} \pm 1.6$ & $8.8^{\mathrm{ab}} \pm 2.4$ \\
\hline $\mathrm{T} 1 \mathrm{~h}$ & $149^{\mathrm{a}} \pm 26.0$ & $101^{\mathrm{a}} \pm 2.0$ & $40.0^{\mathrm{a}} \pm 0.2$ & $2.6^{\mathrm{a}} \pm 0.5$ & $22^{\mathrm{bc}} \pm 3.9$ & $7.0^{\mathrm{bc}} \pm 1.2$ & $13.0^{\mathrm{abc}} \pm 1.4$ & $8.6^{b} \pm 2.2$ \\
\hline T6h & $128^{\mathrm{ab}} \pm 19.0$ & $22^{\mathrm{d}} \pm 5.0$ & $39.2^{c} \pm 0.5$ & $2.5^{\mathrm{a}} \pm 0.5$ & $18^{\mathrm{ecd}} \pm 2.4$ & $5.8^{\mathrm{ecd}} \pm 0.7$ & $12.1^{\mathrm{abc}} \pm 2.3$ & $12.4^{\mathrm{ab}} \pm 3.7$ \\
\hline $\mathrm{T} 12 \mathrm{~h}$ & $118^{\mathrm{bc}} \pm 16.0$ & $22^{\mathrm{d}} \pm 4.0$ & $39.2^{\mathrm{bc}} \pm 0.4$ & $2.2^{\mathrm{a} b} \pm 0.4$ & $17^{\mathrm{ed}} \pm 2.5$ & $5.4^{\mathrm{bc}} \pm 0.8$ & $10.8^{\mathrm{bcd}} \pm 1.5$ & $12.9^{\mathrm{ab}} \pm 3.5$ \\
\hline $\mathrm{T} 24 \mathrm{~h}$ & $98^{\mathrm{cd}} \pm 14.0$ & $23^{\mathrm{cd}} \pm 6.0$ & $39.2^{\mathrm{c}} \pm 0.3$ & $2.4^{\mathrm{a} b} \pm 0.5$ & $17^{\mathrm{ed}} \pm 2.2$ & $5.4^{\mathrm{c}} \pm 0.7$ & $11.2^{\mathrm{abc}} \pm 2.2$ & $11.6^{\mathrm{ab}} \pm 2.5$ \\
\hline $\mathrm{T} 72 \mathrm{~h}$ & $100^{\mathrm{cd}} \pm 12.0$ & $24^{\mathrm{cd}} \pm 6.0$ & $39.3^{\mathrm{cb}} \pm 0.3$ & $2.2^{\mathrm{ab}} \pm 0.4$ & $16^{\mathrm{e}} \pm 2.4$ & $5.1^{\mathrm{cb}} \pm 0.8$ & $10.4^{\mathrm{bcd}} \pm 1.6$ & $9.1^{\mathrm{ab}} \pm 2.4$ \\
\hline $\mathrm{T} 8 \mathrm{~d}$ & $87^{\mathrm{de}} \pm 9.0$ & $36^{\mathrm{b}} \pm 12.0$ & $39.9^{\mathrm{ab}} \pm 0.2$ & $2.1^{\mathrm{ab}} \pm 0.5$ & $19^{\mathrm{ecd}} \pm 2.7$ & $6.1^{\mathrm{ab}} \pm 0.9$ & $10.2^{\mathrm{bcd}} \pm 2.6$ & $11.9^{\mathrm{ab}} \pm 3.1$ \\
\hline T16d & $76^{\mathrm{def}} \pm 6.0$ & $35^{\mathrm{cb}} \pm 9.0$ & $39.4^{\mathrm{abc}} \pm 0.3$ & $1.7^{\mathrm{c}} \pm 0.2$ & $21^{\mathrm{bcd}} \pm 2.3$ & $6.7^{\mathrm{abc}} \pm 0.7$ & $9.5^{\mathrm{cd}} \pm 2.9$ & $14.3^{\mathrm{a}} \pm 5.3$ \\
\hline $\mathrm{T} 24 \mathrm{~d}$ & $63^{\mathrm{ef}} \pm 6.0$ & $22^{\mathrm{d}} \pm 5.0$ & $38.9^{\text {cd }} \pm 0.3$ & $2.1^{\mathrm{ab}} \pm 0.2$ & $25^{\mathrm{ab}} \pm 1.9$ & $8.0^{\mathrm{cd}} \pm 0.6$ & $14.8^{\mathrm{a}} \pm 1.95$ & $11.6^{a b} \pm 3.6$ \\
\hline $\mathrm{T} 32 \mathrm{~d}$ & $59^{\mathrm{f}} \pm 9.0$ & $25^{\mathrm{bcd}} \pm 7.0$ & $39.0^{\mathrm{cd}} \pm 0.2$ & $1.7^{\mathrm{c}} \pm 0.2$ & $25^{\mathrm{ab}} \pm 3.7$ & $8.1^{\mathrm{cd}} \pm 1.2$ & $13.8^{\mathrm{ab}} \pm 2.0$ & $12.2^{\mathrm{ab}} \pm 3.8$ \\
\hline
\end{tabular}

Different lowercase letters in the same column mean significant difference between times $(\mathrm{P}<0.05)$.

There was an average increase of $2{ }^{\circ} \mathrm{C}$ in rectal temperature one hour after blood loss (Table 1). Over time, the mean values decreased, but the return to basal temperatures did not occur until T24d. Although rectal temperatures remained within the reference values for the species (38-40 $\left.{ }^{\circ} \mathrm{C}\right)(\mathrm{PUGH}, 2005)$, the occurrence of hyperthermia may be linked to increased peripheral resistance (to maintain pressure), as well as the release of hormones involved in the production of heat, such as adrenocorticotropic hormones and catecholamines (ABDALLA; ABDELATIF, 2008, 2010). The return to basal temperatures occurred only after remission of the anemia (T24d), indicating that acute blood loss interfered with thermoregulation in these animals.

Packed cell volume was decreased at T1h and remained below baseline until $\mathrm{T} 16 \mathrm{~d}$, returning to reference values (22-38\%) (JAIN, 1993) only after T24d. The hemoglobin concentration was reduced at $\mathrm{T} 1 \mathrm{~h}$ and remained lower than the reference values (8-12 mg/dL) (JAIN, 2003) until T24d. The number of red blood cells was decreased after $\mathrm{T} 12 \mathrm{~h}$ and returned to baseline at T24d (Table 1). It is important to note that the values of this parameter were within the reference range for the species after blood loss $\left(8-18 \times 10^{6} / \mu 1\right)$.

Although packed cell volume decreased in the first hour, the number of red blood cells decreased only later, probably due to hemodilution, which is a physiological and emergency response to blood loss. During this response, fluid moves from the interstitial space into the blood stream due to the reduction of blood pressure, causing the dilution of blood constituents and increasing blood volume. This process is also accompanied by splenic contraction, which is responsible for increasing the number of red blood cells in circulation (CUNNINGHAM, 2004; ABDALLA; ABDELATIF, 2010). The recovery period from anemia in this study was delayed compared to the recovery of goats that suffered losses of $15 \%$ and $30 \%$ of blood volume and recovered in six days or two weeks, respectively (ABDALLA; ABDELATIF, 2008). This longer recovery time may result from the way blood loss was calculated. In this study, eight percent of live 
weight was used to calculate the percentage of total blood volume, while in the study by Abdalla and Abdelatif (2008) they used the more reliable Evan's blue dye technique.

CRT, a physiological variable used to identify hypoperfusion, was shown to be elevated at $\mathrm{T} 1 \mathrm{~h}$, but at $\mathrm{T} 12 \mathrm{~h}$ there was no difference in relation to baseline. The compensatory processes of hemodilution and splenic contraction likely contributed to the reestablishment of CRT 12 hours after blood loss.

The number of leukocytes remained unchanged in relation to T0 (Table 1) and reference values (4$13 \times 10^{3} / \mu 1$ ), indicating a lack of significant immune response after acute blood loss, a finding similar to other studies (ABDALLA; ABDELATIF, 2008). This differed from a study with sheep (SOUSA et al., 2012), which showed that acute blood loss led to an increased leukocyte count. According to Maier (2000), the initial response of the body to hemorrhagic injury is characterized by activation of the immune system and an inflammatory reaction. Although cortisol concentration was not measured, the goats in this study went through a stress period from $\mathrm{T} 1 \mathrm{~h}$ to $\mathrm{T} 6 \mathrm{~h}$, indicated by a significant increase in HR, RR, and blood glucose concentration. However, this was not reflected in the number of total leukocytes, which are routinely elevated in ruminants under stress (FELDMAN et al., 2000).

The concentrations of total protein, globulin, and albumin (Table 2) were decreased one hour after blood loss, and returned to baseline values at T16d, $\mathrm{T} 24 \mathrm{~d}$, and $\mathrm{T} 8 \mathrm{~d}$, respectively. Although albumin was reduced, concentrations remained within the reference values for the species (2.7-3.9 $\mathrm{g} / \mathrm{dL}$ ) throughout the study, while total protein (6.4-7.0 $\mathrm{g} / \mathrm{dL}$ ) and globulin (2.7-3.9 g/dL) were below the reference values up to $\mathrm{T} 24 \mathrm{~d}$ and $\mathrm{T} 24 \mathrm{~h}$, respectively (KANEKO et al., 2008). There was a reduction in non-ionizable serum calcium concentration from $\mathrm{T} 1 \mathrm{~h}$ to $\mathrm{T} 24 \mathrm{~h}$, in relation to the baseline (Table 2), although the calcium concentration was below the reference values until T8d (8.9-11.7 $\mathrm{mg} / \mathrm{dL})$ (KANEKO et al., 2008). Most calcium in the bloodstream is in the non-ionized form (bound to proteins), with albumin being the major binding protein (BARRÊTO-JÚNIOR et al., 2011). When blood loss occurs, calcium is reduced due to protein loss and as a result of hemodilution. As shown in Table 2, the increase in calcium concentration occurred in parallel with the increase in albumin concentration with values returning to baseline at T8d. These findings are corroborated by Abdalla and Abdelatif (2008) in goats and by Sousa et al. (2012) in sheep.

The glucose concentration increased during the period from $\mathrm{T} 1 \mathrm{~h}$ to $\mathrm{T} 6 \mathrm{~h}$ in relation to baseline, and remained above the reference values $(50-75 \mathrm{mg}$ / dL) (KANEKO et al., 2008) for the species until $\mathrm{T} 24 \mathrm{~h}$. The initial glucose concentration was above the reference values and subsequently increased after the loss of blood, possibly due to the release of cortisol and catecholamines that occurs in animals under stress, which promotes an increase in glucose concentration (DUTTON, 2003).

At $\mathrm{T} 1 \mathrm{~h}$ and $\mathrm{T} 24 \mathrm{~h}$ the values of $\mathrm{pH}, \mathrm{TCO}_{2}$, bicarbonate concentration, and base excess (BE) were lower in relation to T0 (Table 3 ). The values of $\mathrm{pH}(7.3-7.5), \mathrm{TCO}_{2}(20.7-30.7 \mathrm{mmol} / \mathrm{L})$, and $\mathrm{pCO}_{2}$ (34.6-48.8 $\mathrm{mmHg}$ ) remained within the reference values for the species (STEVENS et al., 1994; NUNES et al., 2014). However, at T24h the value of the $\mathrm{BE}$ was below the reference values $(-3$ to $+11 \mathrm{mmol} / \mathrm{L})$, while bicarbonate was below reference values $(25-29.4 \mathrm{mmol} / \mathrm{L})$ (STEVENS et al., 1994; NUNES et al., 2014) from T0. The lactate concentration was increased markedly at $\mathrm{T} 1 \mathrm{~h}$ and remained above the reference values up to $\mathrm{T} 72 \mathrm{~h}$ (9.0-12.0 mg/dL) (PUGH, 2005). Reduction in blood volume leads to decreased circulation, causing poor peripheral perfusion of non-vital organs. This increases the production of lactate and $\mathrm{H}+$ ions, resulting in a decrease in $\mathrm{pH}$ as observed, because cells in affected organs enter the anaerobic cycle to maintain adequate levels of energy for metabolism 
(SHIRES; CANIZARO, 1973; ORTOLANI, 2003). At the baseline, the values of both lactate and glucose were above the reference values, possibly due to the containment stress, since adrenaline stimulates the transformation of hepatic glycogen into glucose, as well as promoting the breakdown of glycogen into lactate in tissues such as muscle (LEHNINGER, 1993).

Table 2. Mean and standard deviation of total protein (TP), albumin, globulin, calcium (Ca), glucose, and lactate from goats subjected to phlebotomy ( $30 \%$ blood volume loss) at times T0 (immediately before blood loss), one (T1h), six (T6h), 12 (T12h), 24 (T24h), 72 hours (T72h), and eight (T8d), 16 (T16d), 24 (T24d), and 32 (T32d) days after blood withdrawal.

\begin{tabular}{|c|c|c|c|c|c|c|}
\hline \multirow[b]{2}{*}{ Time } & \multicolumn{6}{|c|}{ Parameters } \\
\hline & $\begin{array}{c}\mathrm{TP} \\
(\mathrm{g} / \mathrm{dL})\end{array}$ & $\begin{array}{l}\text { Albumin }(\mathrm{g} / \\
\mathrm{dL})\end{array}$ & $\begin{array}{l}\text { Globulin } \\
(\mathrm{g} / \mathrm{dL})\end{array}$ & $\begin{array}{c}\mathrm{Ca} \\
(\mathrm{mg} / \mathrm{dL})\end{array}$ & $\begin{array}{l}\text { Glucose } \\
\text { (mg/dL) }\end{array}$ & $\begin{array}{l}\text { Lactate } \\
(\mathrm{mg} / \mathrm{dL})\end{array}$ \\
\hline T0 & $6.7^{\mathrm{a}} \pm 0.5$ & $3.32^{\mathrm{a}} \pm 0.2$ & $3.38^{\mathrm{a}} \pm 0.3$ & $9.1^{\mathrm{a}} \pm 0.4$ & $82.7^{\mathrm{cde}} \pm 9.3$ & $13.4^{\mathrm{bc}} \pm 6.3$ \\
\hline $\mathrm{T} 1 \mathrm{~h}$ & $5.4^{\mathrm{e}} \pm 0.3$ & $2.75^{\mathrm{d}} \pm 0.1$ & $2.65^{\mathrm{de}} \pm 0.2$ & $8.0^{c} \pm 0.5$ & $252.0^{\mathrm{a}} \pm 14.1$ & $78.6^{\mathrm{a}} \pm 7.20$ \\
\hline T6h & $5.4^{\mathrm{e}} \pm 0.3$ & $2.85^{\mathrm{cd}} \pm 0.1$ & $2.55^{\mathrm{e}} \pm 0.2$ & $8.2^{\mathrm{bc}} \pm 0.4$ & $153.1^{\mathrm{b}} \pm 12.6$ & $22.7^{b} \pm 7.0$ \\
\hline $\mathrm{T} 12 \mathrm{~h}$ & $5.5^{\mathrm{de}} \pm 0.2$ & $2.90^{\mathrm{bcd}} \pm 0.1$ & $2.60^{\mathrm{de}} \pm 0.1$ & $8.2^{\mathrm{bc}} \pm 0.4$ & $95.9^{c} \pm 10.5$ & $17.4^{\mathrm{bc}} \pm 5.7$ \\
\hline $\mathrm{T} 24 \mathrm{~h}$ & $5.6^{\mathrm{de}} \pm 0.2$ & $2.92^{\mathrm{bcd}} \pm 0.1$ & $2.68^{\mathrm{de}} \pm 0.1$ & $8.1^{\mathrm{bc}} \pm 0.3$ & $91.1^{\mathrm{cd}} \pm 8.0$ & $12.6^{\mathrm{bc}} \pm 3.8$ \\
\hline $\mathrm{T} 72 \mathrm{~h}$ & $5.8^{\mathrm{cde}} \pm 0.2$ & $2.97^{\mathrm{bcd}} \pm 0.1$ & $2.83^{\mathrm{cde}} \pm 0.1$ & $8.8^{\mathrm{abc}} \pm 0.5$ & $67.1^{\mathrm{e}} \pm 7.9$ & $9.7^{\mathrm{c}} \pm 6.8$ \\
\hline $\mathrm{T} 8 \mathrm{~d}$ & $6.1^{\mathrm{bcd}} \pm 0.2$ & $3.11^{\mathrm{abc}} \pm 0.07$ & $2.99^{\mathrm{bcd}} \pm 0.1$ & $9.1^{\mathrm{a}} \pm 0.3$ & $75.1^{\mathrm{de}} \pm 6.2$ & $14.7^{\mathrm{bc}} \pm 9.1$ \\
\hline T16d & $5.9^{\mathrm{cde}} \pm 0.3$ & $3.00^{\mathrm{bcd}} \pm 0.1$ & $2.90^{\mathrm{cde}} \pm 0.2$ & $8.9^{\mathrm{ab}} \pm 0.4$ & $76.9^{\mathrm{de}} \pm 9.7$ & $13.0^{\mathrm{bc}} \pm 5.4$ \\
\hline $\mathrm{T} 24 \mathrm{~d}$ & $6.3^{\mathrm{abc}} \pm 0.3$ & $3.02^{\mathrm{bcd}} \pm 0.12$ & $3.28^{\mathrm{abc}} \pm 0.1$ & $8.9^{a b} \pm 0.5$ & $69.0^{\mathrm{e}} \pm 6.9$ & $12.9^{\mathrm{bc}} \pm 7.0$ \\
\hline $\mathrm{T} 32 \mathrm{~d}$ & $6.6^{\mathrm{ab}} \pm 0.3$ & $3.15^{\mathrm{ab}} \pm 0.1$ & $3.45^{\mathrm{ab}} \pm 0.2$ & $9.2^{\mathrm{a}} \pm 0.4$ & $70.9^{\mathrm{e}} \pm 4.7$ & $10.7^{\mathrm{bc}} \pm 3.2$ \\
\hline
\end{tabular}

Different lowercase letters in the same column mean significant difference between times $(\mathrm{P}<0.05)$.

Table 3. Mean and standard deviation of $\mathrm{pH}, \mathrm{pCO}_{2}, \mathrm{BE}, \mathrm{HCO}_{3}^{-}$, and $\mathrm{TCO}_{2}$ values from goats subjected to phlebotomy (30\% blood volume loss) at times T0 (immediately before blood loss), one (T1h), six (T6h), 12 (T12h), 24 (T24h), 72 hours (T72h), and eight (T8d), 16 (T16d), 24 (T24d), and 32 (T32d) days after blood withdrawal.

\begin{tabular}{|c|c|c|c|c|c|}
\hline \multicolumn{6}{|c|}{ Parameters } \\
\hline Time & $\mathrm{pH}$ & $\begin{array}{c}\mathrm{pCO}_{2} \\
(\mathrm{mmHg})\end{array}$ & $\begin{array}{c}\mathrm{BE} \\
(\mathrm{mmol} / \mathrm{L})\end{array}$ & $\begin{array}{c}\mathrm{HCO}_{3}^{-} \\
(\mathrm{mmol} / \mathrm{L})\end{array}$ & $\begin{array}{c}\mathrm{TCO}_{2} \\
(\mathrm{mmol} / \mathrm{L})\end{array}$ \\
\hline T0 & $7.36^{\mathrm{ab}} \pm 0.03$ & $41.1^{\mathrm{a}} \pm 3.0$ & $-2.2^{\mathrm{a}} \pm 1.8$ & $22.9^{\mathrm{ab}} \pm 1.4$ & $24.1^{\mathrm{ab}} \pm 1.5$ \\
\hline $\mathrm{T} 1 \mathrm{~h}$ & $7.30^{\mathrm{c}} \pm 0.04$ & $40.9^{\mathrm{ab}} \pm 2.8$ & $-5.6^{\mathrm{bc}} \pm 2.8$ & $20.0^{\mathrm{cd}} \pm 2.1$ & $21.1^{\mathrm{cd}} \pm 2.2$ \\
\hline T6h & $7.37^{\mathrm{ab}} \pm 0.03$ & $38.5^{\mathrm{ab}} \pm 2.2$ & $-2.1^{\mathrm{a}} \pm 1.2$ & $22.1^{\mathrm{abc}} \pm 1.1$ & $23.1^{\mathrm{abc}} \pm 1.3$ \\
\hline $\mathrm{T} 12 \mathrm{~h}$ & $7.38^{\mathrm{ab}} \pm 0.01$ & $36.5^{\mathrm{ab}} \pm 2.6$ & $-3.2^{a b c} \pm 1.5$ & $21.1^{\mathrm{bcd}} \pm 1.4$ & $22.1^{\mathrm{bcd}} \pm 1.3$ \\
\hline $\mathrm{T} 24 \mathrm{~h}$ & $7.34^{\mathrm{bc}} \pm 0.03$ & $36.0^{\mathrm{b}} \pm 3.0$ & $-5.7^{\mathfrak{c}} \pm 2.2$ & $19.2^{\mathrm{d}} \pm 1.9$ & $20.1^{\mathrm{d}} \pm 2.0$ \\
\hline $\mathrm{T} 72 \mathrm{~h}$ & $7.37^{\mathrm{ab}} \pm 0.02$ & $38.4^{\mathrm{ab}} \pm 3.5$ & $-2.3^{\mathrm{ab}} \pm 2.5$ & $22.1^{\mathrm{abc}} \pm 2.1$ & $23.2^{\mathrm{abc}} \pm 2.3$ \\
\hline $\mathrm{T} 8 \mathrm{~d}$ & $7.35^{\mathrm{bc}} \pm 0.03$ & $40.9^{a b} \pm 2.8$ & $-2.8^{a b c} \pm 1.6$ & $22.1^{\mathrm{abc}} \pm 1.2$ & $23.2^{\mathrm{abc}} \pm 1.4$ \\
\hline T16d & $7.40^{\mathrm{a}} \pm 0.03$ & $38.5^{\mathrm{ab}} \pm 3.8$ & $-0.6^{\mathrm{a}} \pm 2.6$ & $24.5^{\mathrm{a}} \pm 1.2$ & $25.5^{\mathrm{a}} \pm 1.2$ \\
\hline $\mathrm{T} 24 \mathrm{~d}$ & $7.38^{\mathrm{ab}} \pm 0.00$ & $36.2^{\mathrm{ab}} \pm 2.1$ & $-3.3^{\mathrm{abc}} \pm 1.7$ & $21.2^{\mathrm{bcd}} \pm 1.4$ & $22.2^{\mathrm{bcd}} \pm 1.4$ \\
\hline $\mathrm{T} 32 \mathrm{~d}$ & $7.41^{\mathrm{a}} \pm 0.02$ & $36.1^{\mathrm{ab}} \pm 3.7$ & $-1.0^{\mathrm{a}} \pm 1.3$ & $22.7^{\mathrm{abc}} \pm 1.7$ & $24.3^{\mathrm{ab}} \pm 1.3$ \\
\hline
\end{tabular}

Different lowercase letters in the same column mean significant difference between times $(\mathrm{P}<0.05)$. 
Because bicarbonate acts as a $\mathrm{pH}$ buffer, the low $\mathrm{pH}$ caused a decrease in its concentration, resulting in the observed deficit of this compound. Hyperventilation, due an increase in the RR, was responsible for the decrease of $\mathrm{TCO}_{2}$, while $\mathrm{pCO}_{2}$ was lower only at $\mathrm{T} 24 \mathrm{~h}$.

The systolic, diastolic, and mean pressures were affected similarly throughout the evaluation. At $\mathrm{T} 1 \mathrm{~h}$, the values were lower than half of those observed at T0, and lower than the reference values (SP: 107 to $121 \mathrm{mmHg}$, DP: 71 to $87 \mathrm{mmHg}$, MP: 85 to $104 \mathrm{mmHg}$ ) (DZIKITI et al., 2011). The values recovered at the later times (Table 4). This rapid elevation of pressure occurs due to the immediate release of catecholamines during significant blood loss, causing an increase in peripheral vascular resistance (CUNNINGHAM, 2004). The return of these pressures after $\mathrm{T} 1 \mathrm{~h}$ to the baseline values, while other parameters indicative of tissue perfusion (CRT, $\mathrm{HR}, \mathrm{RR}$, blood $\mathrm{pH}, \mathrm{TCO}_{2}, \mathrm{BE}$, and bicarbonate) were still affected, demonstrates that blood pressure is not a good indicator of perfusion. This finding was also reported by Dourado (2010).

Table 4. Mean values and standard deviation of the systolic pressure (SP), diastolic pressure (DP), and mean pressure (MP) of goats subjected to phlebotomy (30\% blood volume loss) at times T0 (immediately before blood loss), T1 (immediately after blood loss), one (T1h), six (T6h), and 12 (T12h) hours after blood loss.

\begin{tabular}{cccccc}
\hline \multirow{2}{*}{ Parameters } & \multicolumn{5}{c}{ Times } \\
\cline { 2 - 6 } & T0 & T1 & T1h & T6h & T12h \\
\hline SP $(\mathrm{mmHg})$ & $126^{\mathrm{a}} \pm 17.0$ & $47^{\mathrm{c}} \pm 16.0$ & $106^{\mathrm{ab}} \pm 20.0$ & $102^{\mathrm{ab}} \pm 21.0$ & $96^{\mathrm{b}} \pm 11.0$ \\
DP (mmHg) & $72^{\mathrm{a}} \pm 13.0$ & $23^{\mathrm{b}} \pm 17.0$ & $63^{\mathrm{a}} \pm 21.0$ & $70^{\mathrm{a}} \pm 19.0$ & $73^{\mathrm{a}} \pm 13.0$ \\
$\mathrm{MP}(\mathrm{mmHg})$ & $97^{\mathrm{a}} \pm 9.0$ & $40^{\mathrm{b}} \pm 22.0$ & $86^{\mathrm{a}} \pm 13.0$ & $82^{\mathrm{a}} \pm 21.0$ & $86^{\mathrm{a}} \pm 12.0$ \\
\hline
\end{tabular}

Different lowercase letters in the same column mean significant difference between times $(\mathrm{P}<0.05)$.

Biochemical analyses of AST and GGT activity, and urea and creatinine concentrations (data not shown) were performed to assess the influence of blood loss on the kidneys and liver of the animals, since severe blood loss may cause pre-renal azotemia and alterations in liver enzymes, due to tissue hypoxia (SOUSA et al., 2012). However, these variables remained within the reference values for the species, indicating that the induced blood loss did not cause damage to these organs.

The acute loss of $30 \%$ of total blood volume in goats caused changes in clinical, blood gas, biochemical, and cardiovascular parameters that were compensated for within the first six hours, while hematological changes were more persistent, with basal values restored only after 24 days.

\section{References}

ABDALLA, S. E.; ABDELATIF, A. M. Effect of haemorrhage on thermoregulation, heart rate and blood constituents in goat (Capra hircus). Pakistan Journal of Biological Science, Faisalabad, v. 11, n. 9, p. 1194-1203, 2008.

Physiological responses of goats (Capra hircus) to haemorrhage as influenced by splenectomy. AmericanEurasian Journal of Scientific Research, Dubai, v. 5, n. 2, p. 76-87, 2010.

BAGINSKI, E. S.; MARIE, S. S.; CLARK, W. L.; ZAK, B. Direct microdetermination of serum calcium. Clinica Chemica Acta, Amsterdam, v. 46, n. 1, p. 46-54, 1973.

BARHAM, D.; TRINDER, P. An improved color reagent for the determination of blood glucose by the oxidase system. Analyst, Cambridge, v. 97, n. 1151, p. 142-145, 1972. 
BARRÊTO JÚNIOR, R. A.; MINERVINO, A. H. H.; RODRIGUES, F. A. M. L.; MEIRA JUNIOR, E. B. S.; FERREIRA, R. N. F.; LIMA, A. S.; MORI, C. S.; BARROS, I. O.; ORTOLANI, E. L. Avaliação do quadro clínico e perfil bioquímico de bovinos durante indução e tratamento de hipocalcemia. Brazilian Journal of Veterinary Research and Animal Science, São Paulo, v. 48, n. 3, p. 192-199, 2011.

BARTELS, H.; BOHMER, M. Serum creatinine determination without protein precipitation. Clínica Chimica Acta, Amsterdam, v. 37, n. 1, p. 193-197, 1972.

COSTA, A. R.; LACERDA, C.; FREITAS, F. R. D. A criação de ovinos e caprinos em Campos Sales - CE. Cadernos de Cultura e Ciência, Crato, v. 2, n. 2, p. 5563, 2010.

CUNNINGHAM, J. G. Tratado de fisiologia veterinária. 3. ed. Rio de Janeiro: Guanabara Koogan, 2004. 624 p.

DORR, L.; PEARCE, P. C.; SHINE, T.; HAWKEY, C. $M$. Changes in red cell volume distribution frequency after acute blood loss in goats. Research in Veterinary Science, Amsterdam, v. 40, n. 3, p. 322-327, 1986.

DOURADO, A. J. S. Estudo de variações de gasometria venosa e indicadores de perfusão em canídeos em sindrome choque. 2010. Dissertação (Mestrado Integrado em Medicina Veterinária) - Faculdade de Medicina Veterinária. Universidade Técnica de Lisboa, Lisboa.

DUTTON, R. P. Pathophysiology of the traumatic shock. Massive transfusion and control of hemorrhage in the trauma patient. Baltimore: The International Trauma Anesthesia and Critical Care Society (ITACCS), 2003. $52 \mathrm{p}$.

DZIKITI, B. T.; STEGMANN, F. G.; CROMARTY, D.; DZIKITI, L. N.; HELLEBREKERS, L. J. Effects of propofol on isoflurane minimum alveolar concentration and cardiovascular function in mechanically ventilated goats. Veterinary Anaesthesia and Analgesia, Amsterdam, v. 38, n. 1, p. 44-53, 2011

FELDMAN, B. F.; ZINKL, J. G.; JAIN, N. C. Schalm's veterinary. $5^{\text {th }}$ ed. Philadelphia: Lippincott Williams \& Williams, 2000. 1344 p.

HAUPTMAN, J.; CHAUDRY, I.H. Choque: fisioterapia e tratamento da hipovolemia e infecção/septicemia. In: SLATTER, D. Manual de cirurgia de pequenos animais. $2^{\text {nd }}$ ed. São Paulo: Manole, 1998. p. 1-12.

HENDRIX, C. M. Procedimentos laboratoriais para técnicos veterinários. 4. ed. São Paulo: Roca, 2005. 576 p.

JAIN, N. C. Essentials of veterinary hematology. Philadelphia: Lea \& Febiger, 1993. 411 p.
JOHNSON, A. M.; ROHLFS, E. M.; SILVERMAN, L. M. Proteins. In: BURTIS, C. A.; ASHWOOD, E. R. Tietz textbook of clinical chemistry. $3^{\text {th }}$ ed. Philadelphia: W.B. Saunders Company, 1999. p. 477-540.

KANEKO, J. J.; HARVEY, J. W.; BRUSS, M. L. Clinical biochemestry of domestic animals. $6^{\text {th }}$ ed. San Diego: Academic Press, 2008. 916 p.

LEHNINGER, A. L. Princípios de bioquímica. São Paulo: Sarvier, 1993. 725 p.

LIPINSKA, S.; FORYS, S.; LIPINSKA, A. Posthaemorrhage vasopressin release. Journal Physiological Pharmacology, Kraków, v. 55, n. 1, p. 73-83, 2004.

MAIER, R. V. Pathogenesis of multiple organ dysfunction syndrome: endotoxin, inflammatory cells, and their mediators: cytokines and reactive oxygen species. Surgical Infections, New Rochelle, v. 1, n. 3, p. 197-205, 2000.

MANTOVANI, M.; FONTELLES, M. J.; HIRANO, E. S.; MORANDIN, R. C.; CAPUTO, L. R. G.; SCHENKA, A. A. Isquemia e reperfusão hepática total associada ao estado de choque hemorrágico controlado: efeitos no sequestro de neutrófilos no pulmão do rato. Acta Cirúrgica Brasileira, São Paulo, v. 17, n. 1, p. 4654, 2002.

NUNES, T. L.; OLIVEIRA, M. G. C.; PAIVA, A. L. C.; BEZERRA, T. C. G.; BARRÊTO JÚNIOR, R. A.; PAULA, V. V. Valores hemogasométricos de caprinos (Capra hircus) da raça Canindé criados no semiárido nordestino. Revista Brasileira de Medicina Veterinária, Rio de Janeiro, v. 36, n. 3, p. 255-260, 2014.

ORTOLANI, E. L. Diagnóstico e tratamento de alterações ácido-básicas em ruminantes. In: SIMPÓSIO DE PATOLOGIA CLÍNICA VETERINÁRIA DA REGIÃO SUL DO BRASIL, 1., 2003, Porto Alegre. Anais... Porto Alegre: Universidade Federal do Rio Grande do Sul/ Faculdade de Medicina Veterinária, 2003. p. 17-29.

PUGH, D. G. Clínica de ovinos e caprinos. São Paulo: Roca, 2005. $513 \mathrm{p}$.

REITMAN, S.; FRANKEL S. A colorimetric method for the determination of serum glutamic oxalacetic and glutamic pyruvic transaminase. American Journal of Clinical Pathology, Cary, v. 28, n. 1, p. 56-63, 1957.

SAEEDI, M.; HAJISEYEDJAVADI, H.; VAHDATI, S. S.; ESLAMI, V.; MOKHTARPOUR, M.; MOMENI, M.; FARNIA, M. R.; NEJAD, N. H. Hypertonic saline, normal saline or neither: which is best for uncontrolled hemorrhagic shock? An experimental study in goats. Ulusal Travma ve Acil Cerrahi Dergisi, Istanbul, v. 19, n. 6, p. 500-506, 2013. 
SHIMOJO, N.; NAKA, K.; NAKAJIMA, C.; YOSHIKAWA, C.; OKUDA, K.; OKADA, K. Test -strip method for measuring lactate in whole blood. Clinical Chemistry, Washington, v. 35, n. 9, p. 1992-1994, 1989.

SHIRES, T.; CANIZARO, P. C. Fluid resuscitation in the severly injured. The Surgical Clinics of North America, Amsterdam, v. 53, n. 6, p. 1341-1366, 1973.

SILVERTHORN, D. U. Fisiologia humana: uma abordagem integrada. 5. ed. Porto Alegre: Artmed, 2010. $992 \mathrm{p}$.

SOUSA, R. S.; CHAVES, D. F.; BARRÊTO-JÚNIOR, R. A.; SOUSA, I. K. F.; SOARES, H. S.; BARROS, I. O.; MINERVINO, A. H. H.; ORTOLANI, E. L.; BARRÊTO JÚNIOR, R. A. Clinical, haematological and biochemical responses of sheep undergoing autologous blood transfusion. BMC Veterinary Research, London, v. 8, Article ID:61, 2012.

STARR，J.; WELCH，R. D.; EASTRIDGE，B. J.; PIERCE, W.; ZHANG, H. The effect of hemorrhagic shock in a caprine tibial fracture, model. Journal of Orthopaedic Trauma, Philadelphia, v. 16, n. 4, p. 250256, 2002.
STEVENS, J. B.; ANDERSON, K. L.; CORREA, M. T.; STEWART, T.; BRASELTON JÚNIOR, W. E. Hematologic, blood gas, blood chemistry, and serum mineral values for a sample of clinically healthy adult goats. Veterinary Clinical Pathology, Hoboken, v. 23, n. 1, p. 19-24, 1994.

SZASZ, G. A kinetic photometric method for serum gamma-glutamyl transpeptidase. Clinical Chemistry, Washington, v. 15, n. 2, p. 124-136, 1969.

TOMAS, H. Clinical laboratory diagnostics. Frankfurt: TH-Books Verlagsgesellschaft, 1998. 1527 p.

WIJFFELS, M. C. E. F.; TIMMERMANS, C. C. M. M.; VAN SUYLEN, R. J.; RODRIGUEZ, L. M. Internal atrial shock delivery by standard diagnostic electrophysiology catheters in goats: effects on atrial electrogram amplitude and tissue architecture. Europace, Oxford, v. 9, n. 4, p. 203-207, 2007. 